\title{
Phosphorus Fertilization Differentially Influences Fatty Acids, Protein, and Oil in Soybean
}

\author{
Xinhua Yin 1*, Nacer Bellaloui'², Angela M. McClure', Don D. Tyler ${ }^{3}$, Alemu Mengistu ${ }^{4}$ \\ ${ }^{1}$ Department of Plant Sciences, The University of Tennessee, Jackson, TN, USA \\ ${ }^{2}$ Crop Genetics Research Unit, USDA-ARS, Stoneville, MS, USA \\ ${ }^{3}$ Crop Genetics Research Unit, USDA-ARS, Jackson, TN, USA \\ ${ }^{4}$ Department of Biosystems Engineering and Soil Science, The University of Tennessee, Jackson, TN, USA \\ Email: xyin2@utk.edu
}

How to cite this paper: Yin, X.H., Bellaloui, N., McClure, A.M., Tyler, D.D. and Mengistu, A. (2016) Phosphorus Fertilization Differentially Influences Fatty Acids, Protein, and Oil in Soybean. American Journal of Plant Sciences, 7, 1975-1992.

http://dx.doi.org/10.4236/ajps.2016.714180

Received: September 3, 2016

Accepted: October 14, 2016

Published: October 17, 2016

Copyright $\odot 2016$ by authors and Scientific Research Publishing Inc. This work is licensed under the Creative Commons Attribution International License (CC BY 4.0).

http://creativecommons.org/licenses/by/4.0/ (c) (i) Open Access

\section{Abstract}

Information is limited about phosphorus $(\mathrm{P})$ fertilization effects on soybean seed composition. A field experiment was conducted to investigate the effects of $\mathrm{P}$ application rates on the concentrations of various fatty acids, protein, and oil in soybean under no-tillage on low and high testing $\mathrm{P}$ soils at Jackson and Milan, Tennessee from 2008 through 2011. Five P rates $0,10,20,30$, and $40 \mathrm{~kg} \cdot \mathrm{P} \cdot \mathrm{ha}^{-1}$ plus the recommended $\mathrm{P}$ fertilizer rate based on soil $\mathrm{P}$ testing results were arranged in a randomized complete block design with four replicates. Protein, oil, and fatty acid concentrations in seed responded differently to $\mathrm{P}$ fertilization. In general, protein concentrations were enhanced but oil levels decreased with increased $\mathrm{P}$ application rate. Palmitic and oleic concentrations responded positively to $\mathrm{P}$ application rate up to a certain level. However, the response of linolenic acid concentration was inconsistent (negative or positive). Stearic concentration was not influenced by $P$ fertilization. Application of $10 \mathrm{~kg} \cdot \mathrm{P} \cdot \mathrm{ha}^{-1}$ resulted in higher production of protein and palmitic, oleic, and linolenic acids than zero $\mathrm{P}$ and the higher $\mathrm{P}$ application rates as well on the $\mathrm{P}$ deficient soil. Excessive P application rates could lower seed yield and the quality of some attributes in seed. In conclusion, linoleic acid concentration, a key quality attribute in soybean seed for human and animal consumption, can sometimes be enhanced by $\mathrm{P}$ fertilization; the indigenous soil $\mathrm{P}$ level and $\mathrm{P}$ application rate should be taken into account in breeding soybean cultivars with low linolenic acid level.

\section{Keywords}

Phosphorus, Fatty Acids, Protein, Oil, Yield, Soybean 


\section{Introduction}

Soybean [Glycine $\max$ (L.) Merr.] is traditionally grown for protein and oil in the seed. Soybean seed grown in the United States contains approximately $41 \%$ protein and $21 \%$ oil on a dry weight basis [1]. In addition, soybean contains about $33 \%$ carbohydrates [2] and secondary metabolites such as phenolics including isoflavones [3]. There are five major fatty acids (palmitic acid, stearic acid, oleic acid, linoleic acid, and linolenic acid) and three major isoflavones (daidzein, genistein, and glycitein) in soybean seed [4] [5].

Soybean seed quality attributes are affected by both genetics [1] [6] and the environment [7] [8]. Genotype and maturity [9]-[11], planting date [12] [13], temperature [7], drought [10] [14], and nutrients in soil and seed [15]-[17] are among the genetic and environmental factors. For instance, Helms et al. (1990) [13] found that soybean seed attributes varied in the same cultivar grown in different years or under different environments in the same year, and seed protein concentration increased as planting date was delayed. Burton (1985) [18] and Shannon et al. (1972) [19] reported a negative relationship of seed protein concentration with seed yield of soybean.

Although nutrient management effects on soybean seed yield and protein and oil concentrations have been examined in previous studies [17] [20]-[22], its impacts on the concentrations of fatty acids in soybean seed have been scarcely investigated [23]. Since $\mathrm{N}$ fertilization is usually not needed, primarily $\mathrm{P}$ and $\mathrm{K}$ have been studied. Fertilization with $\mathrm{P}$ and $\mathrm{K}$ can influence soybean yield and various physiological processes that, in turn, could affect seed yield and protein and oil concentrations [24]. Seed composition can be altered with $\mathrm{P}$ fertilization although these alterations have been reported to be moderate and inconsistent [20] [23] [25] [26]. Abbasi et al. (2012) [27] observed that $\mathrm{P}$ application increased both protein and oil concentrations in soybean seed. However, Haq and Mallarino (2005) [20] found that P fertilization increased protein and oil concentrations in some trials but decreased protein and oil levels in some other trials. Krueger et al. (2013) [22] reported that protein and oil concentrations in soybean seed were not affected by $\mathrm{P}$ fertilization at most locations. Gaydou and Arrivets (1983) [25], Israel et al. (2007) [28], and Krueger et al. (2013) [23] confirmed that linoleic acid concentration decreased with P fertilization. Gaydou and Arrivets (1983) [25] and Israel et al. (2007) [28] also observed an increase in oleic acid concentration at higher P application rates. Krueger et al. (2013) [23] reported that linolenic acid concentration increased with excessively high $\mathrm{P}$ fertilization.

With the increased interest in eliminating trans fatty acids in the diets of Americans, soybean breeders continue to place more emphasis on developing varieties which can produce seed with elevated levels of desired fatty acids such as oleic acid. If a market premium is offered for specific seed quality attributes, soybean growers will need information on how to improve their seed quality. The main objective of this study was to evaluate $\mathrm{P}$ application rate effects on the concentrations and production of palmitic acid, stearic acid, oleic acid, linoleic acid, linolenic acid, protein, and oil of soybean under no-tillage on low to high testing P soils. 


\section{Materials and Methods}

\subsection{Site Description and Experimental Design and Implementation}

The P fertilization effects on seed quality attributes and yields of soybean were investigated in a small plot field experiment that was conducted on the University of Tennessee's West Tennessee Research and Education Center at Jackson and University of Tennessee's Research and Education Center at Milan from 2008 to 2011. The fields used for this study were classified as Memphis silt loam at Jackson and Dexter loam at Milan, which had been under continuous no-till production for more than 10 years before experiment establishment. The previous crop was soybean at both locations in 2007.

A randomized complete block design was used with six $\mathrm{P}$ treatments repeated four times at both locations each year. The first five treatments consisted of the following five $\mathrm{P}$ application rates: $0,10,20,30$, and $40 \mathrm{~kg} \cdot \mathrm{P} \cdot \mathrm{ha}^{-1}$ (equal to $0,20,40,60$, and $80 \mathrm{lb}$ $\mathrm{P}_{2} \mathrm{O}_{5} \mathrm{a}^{-1}$ ). The last treatment was the recommended $\mathrm{P}$ application rate based on soil $\mathrm{P}$ testing results every year. The recommended $\mathrm{P}$ rates for Milan were 22, 0,10 , and 0 $\mathrm{kg} \cdot \mathrm{ha}^{-1}$ and the rates for Jackson were 15, 0, 0, and $10 \mathrm{~kg} \cdot \mathrm{ha}^{-1}$ for 2008, 2009, 2010, and 2011, respectively. The $\mathrm{P}$ fertilizer was uniformly applied on the soil surface by hand as triple superphosphate (0N-20P-0K). Plots were $9.1 \mathrm{~m}$ long and $3.0 \mathrm{~m}$ wide. A full season soybean "Pioneer 94M80" crop was no-till planted in 76-cm rows at both locations in all four seasons. No winter crop was grown in any year in this study. The planting dates were 6 May 2008, 12 May 2009, 6 May 2010, and 11 May 2011 at Jackson and 23 May 2008, 20 May 2009, 13 May 2010, and 2 June 2011 at Milan. A uniform rate of potash fertilizer was applied as needed according to the soil $\mathrm{K}$ testing results each year [29]. Pests, weeds, and diseases were controlled with the University of Tennessee Extension Service's recommended management practices for soybean. The identical plot and treatment layout was used in the same area of the same field at both locations for all four years. The daily air temperatures and rainfall were recorded at both locations each year.

Soybean yields were determined at maturity with a plot combine by harvesting the center two rows for the entire plot length from each plot on 29 September 2008, 21 October 2009, 21 September 2010, and 30 September 2011 at Jackson and 2 October 2008, 19 October 2009, 20 September 2010, and 30 September 2011 at Milan. The yields were adjusted to $130 \mathrm{~g} \mathrm{~kg}^{-1}$ moisture content.

\subsection{Soil P Testing}

A composite soil sample consisting of 10 cores was randomly collected at the $0-15 \mathrm{~cm}$ depth from each plot with a $2.5-\mathrm{cm}$ diameter hand soil probe at Jackson and Milan before P treatments were applied on 3 March and 9 April 2008, respectively. After soil samples were air-dried, ground to pass a $2-\mathrm{mm}$ screen, and thoroughly mixed, they were analyzed for basic properties by the University of Tennessee's Soil, Plant, and Pest Center (Nashville, TN). Soil pH was determined in a 1:1 (soil: $\left.\mathrm{H}_{2} \mathrm{O}\right)$ solution (Watson and Brown, 1998). Soil available $\mathrm{NH}_{4}{ }^{+}, \mathrm{NO}_{3}{ }^{-}, \mathrm{P}, \mathrm{K}, \mathrm{Ca}$, and $\mathrm{Mg}$ were extracted with the 
Mehlich I method [30].

A composite soil sample was also taken from each plot at soybean harvest each year for soil available $\mathrm{P}$ which was determined with the same method as stated above. The specific sampling dates were 9 October 2008, 4 November 2009, 1 November 2010, and 1 December 2011 at Jackson and 28 October 2008, 5 November 2009, 5 October 2010, and 6 October 2011 at Milan.

\subsection{Analyses of Leaf and Seed P Concentrations}

A composite leaf sample composed of 20 most recently fully developed trifoliate leaves with petioles was randomly collected at approximately the V5, R1, and R3 growth stages from each plot at both locations in all four seasons for the determination of total $\mathrm{P}$ concentrations. The specific sampling dates were 8 July 2008, 26 June 2009, 14 June 2010, and 21 June 2011 at Jackson and 9 July 2008, 29 June 2009, 17 June 2010, and 13 July 2011 at Milan for V5; 16 July 2008, 6 July 2009, 21 June 2010, and 21 July 2011 at Jackson and 17 July 2008, 7 July 2009, 28 June 2010, and 25 July 2011 at Milan for R1; and 28 August 2008, 27 July 2009, 26 July 2010, and 1 August 2011 at Jackson; 29 August 2008, 23 July 2009, 28 July 2010, and 4 August 2011 at Milan for R3. A composite seed sample was taken at harvest from each plot at both locations during 2008-2010 for analyses of $\mathrm{P}$ concentrations. Leaf and seed samples were dried at $65^{\circ} \mathrm{C}$ in a forced air oven for at least $3 \mathrm{~d}$ and then ground in a Wiley mill (Arthur K. Thomas Co., Philadelphia, PA) to pass a 1-mm screen. Total P in each leaf and seed sample was digested with nitric acid and hydrogen peroxide in a CEM MDS 2100 series microwave (CEM Corporation, Matthews, NC), and the digested solution was analyzed on a Thermo Jarrel Ash 1100 ICP [31].

\subsection{Determination of Protein, Oil, and Fatty Acid Concentrations in Seed}

Seed samples collected at harvest were also analyzed for protein, oil, and fatty acid concentrations at both locations during 2008-2010. Approximately $25 \mathrm{~g}$ of seed from each plot was ground with a Laboratory Mill 3600 (Perten, Springfield, IL) and analyzed with near infrared reflectance [9] [32] using a diode array feed analyzer AD 7200 (Perten, Springfield, IL). Calibrations were initially developed by the University of Minnesota, using Perten's Thermo Galactic Grams PLS IQ software. Protein and oil concentrations were expressed on a dry seed basis [32] [33], while fatty acids (palmitic, stearic, oleic, linoleic, and linolenic acids) were expressed on an oil basis. The production of protein or oil was defined as the product of soybean seed yield level and the concentration of protein or oil in the seed. Since the concentrations of fatty acids were expressed on an oil basis, the production of each of these fatty acids was defined as the product of soybean oil production and the concentration of specific fatty acid in the seed oil.

\subsection{Statistical Analysis}

Analyses of variance were conducted for the concentrations and production of protein, 
oil, and fatty acids in each individual year at each location with the ANOVA procedure in SAS for Windows V9 (2) (SAS Institute, Cary, NC). A randomized complete block design with four replications was used for all these analyses. Data combined across the three or four years at each location were analyzed under a randomized complete block design with year as a random factor. Treatment or year means were separated with the Fisher's protected LSD test if needed. Probability levels lower than 0.05 were designated as significant.

\section{Results and Discussion}

Weather conditions were different among the four years at Jackson and Milan (Table 1). It was obvious that 2010 was hotter during May to October, and 2011 was hotter in July, than 2008 and 2009 at both locations. During 2010, both locations received heavy rains totaling $370 \mathrm{~mm}$ on 1 and 2 May 2010 but suffered reduced late season moisture. In contrast, the 2008 growing season was generally dry throughout the season at Milan with poor late season moisture at Jackson.

\subsection{Soil P Levels}

According to the present Tennessee soil-test $\mathrm{P}$ interpretations, soil $\mathrm{P}$ fertility is categorized as low, medium, high, and very high for soybean when soil-test $\mathrm{P}$ concentration is 0 - 9, $10-15,16-59, \geq 60 \mathrm{mg} \mathrm{P} \mathrm{kg}^{-1}$ (equivalent to $0-18,19-30,31-119$, and $\geq 120 \mathrm{lb}$ $\mathrm{P} \mathrm{a}^{-1}$ ), respectively, with Mehlich I as the extractant [29]. Based on the above criteria, the initial soil $\mathrm{P}$ fertility under Mehlich I was high $\left(21.5 \mathrm{mg} \mathrm{P} \mathrm{kg}^{-1}\right)$ at Jackson but low (6.9 $\mathrm{mg} \mathrm{P} \mathrm{kg}^{-1}$ ) at Milan based on a composite soil sample which was taken from the

Table 1. Monthly average air temperature and rainfall during the growing season at Jackson and Milan, TN from 2008 to 2011.

\begin{tabular}{|c|c|c|c|c|c|c|c|c|c|}
\hline \multirow{2}{*}{ Location } & \multirow{2}{*}{ Month } & \multicolumn{4}{|c|}{ Temperature } & \multicolumn{4}{|c|}{ Rainfall } \\
\hline & & 2008 & 2009 & 2010 & 2011 & 2008 & 2009 & 2010 & 2011 \\
\hline & & \multicolumn{4}{|c|}{${ }^{\circ} \mathrm{C}$} & \multicolumn{4}{|c|}{$\mathrm{mm}$} \\
\hline \multirow[t]{6}{*}{ Jackson } & May & 19.9 & 20.5 & 22.2 & 19.9 & 174.2 & 191.0 & 566.4 & 211.8 \\
\hline & June & 25.7 & 25.7 & 27.6 & 26.3 & 71.4 & 91.7 & 163.6 & 156.2 \\
\hline & July & 26.9 & 24.7 & 28.0 & 28.2 & 159.5 & 187.5 & 168.9 & 95.3 \\
\hline & August & 25.6 & 25.1 & 28.0 & 26.7 & 64.8 & 76.5 & 125.0 & 42.4 \\
\hline & September & 22.9 & 23.1 & 23.3 & 20.1 & 20.1 & 184.4 & 28.2 & 82.8 \\
\hline & October & 15.9 & 14.4 & 16.4 & 14.5 & 80.0 & 176.3 & 35.8 & 28.2 \\
\hline \multirow[t]{6}{*}{ Milan } & May & 19.2 & 20.1 & 21.8 & 19.7 & 233.7 & 229.6 & 534.7 & 285.5 \\
\hline & June & 25.3 & 26.0 & 27.5 & 26.4 & 38.6 & 56.4 & 82.0 & 172.7 \\
\hline & July & 26.5 & 24.6 & 27.6 & 27.9 & 79.2 & 200.9 & 150.6 & 36.1 \\
\hline & August & 25.1 & 24.5 & 27.8 & 26.4 & 18.8 & 56.6 & 50.0 & 29.0 \\
\hline & September & 22.5 & 22.4 & 23.1 & 21.0 & 9.9 & 119.9 & 9.1 & 259.3 \\
\hline & October & 15.1 & 13.9 & 15.9 & 14.6 & 65.0 & 207.8 & 48.5 & 27.2 \\
\hline
\end{tabular}


two locations during November to December 2007, prior to the initiation of this study. Soil $\mathrm{P}$ concentrations before the treatment imposition in spring 2008 did not differ statistically among the plots assigned to the different $\mathrm{P}$ treatments, indicating that the two fields were generally uniform in soil $\mathrm{P}$ fertility prior to this study (Table 2).

At Jackson, soil $\mathrm{P}$ levels did not differ among the $\mathrm{P}$ treatments after soybean harvest in the fall of 2008, 2010, or 2011 (Table 2). However, $\mathrm{P}$ effects were significant on postharvest soil $\mathrm{P}$ with application of $40 \mathrm{~kg} \cdot \mathrm{P} \cdot \mathrm{ha}^{-1}$ resulting in the highest soil $\mathrm{P}$ level in 2009. At Milan, soil $P$ levels were not different among the $P$ treatments after soybean harvest in the fall of 2008, 2009, or 2010, but differed in the fall of 2011 (Table 2). Soil P concentration was the highest when $40 \mathrm{~kg} \cdot \mathrm{P} \cdot \mathrm{ha}^{-1}$ was applied in 2011.

According to the boundaries of soil-test P with Mehlich I as the extractant for soybean in Tennessee [29], soil P fertility was all in the high category, even under the zero $\mathrm{P}$ treatment at both locations in fall 2011 by the end of this study. These ratings were generally identical as those in spring 2008 prior to the treatment imposition of this study. It was unexpected that soil $\mathrm{P}$ did not suffer noticeable decrease even under the zero $\mathrm{P}$ treatment for continuous four years of soybean production at either location.

Table 2. Phosphorus fertilization effects on soil P concentrations at Jackson and Milan from 2008 to 2011.

\begin{tabular}{|c|c|c|c|c|c|c|}
\hline \multirow{2}{*}{ Location } & \multirow{2}{*}{ Treatment $^{\mathrm{a}}$} & \multicolumn{2}{|c|}{2008} & \multirow{2}{*}{$\begin{array}{c}2009 \\
\text { Post-harvest }\end{array}$} & \multirow{2}{*}{$\frac{2010}{\text { Post-harvest }}$} & \multirow{2}{*}{$\begin{array}{c}2011 \\
\text { Post-harves }\end{array}$} \\
\hline & & Pre-plant & Post-harvest & & & \\
\hline & & & & $\mathrm{mg} \cdot \mathrm{kg}^{-1}$ & & \\
\hline \multirow[t]{7}{*}{ Jackson } & 1 & 26.9 & 21.4 & $17.1 b^{b}$ & 34.3 & 25.9 \\
\hline & 2 & 23.0 & 20.9 & $20.9 b$ & 28.6 & 26.1 \\
\hline & 3 & 28.6 & 23.8 & $18.1 \mathrm{~b}$ & 30.4 & 20.5 \\
\hline & 4 & 26.5 & 24.0 & $17.4 \mathrm{~b}$ & 33.8 & 33.9 \\
\hline & 5 & 28.8 & 28.1 & $29.4 a$ & 31.4 & 30.6 \\
\hline & 6 & 26.0 & 20.1 & $18.4 \mathrm{~b}$ & 22.9 & 26.6 \\
\hline & $\mathrm{Sig}^{\mathrm{c}}$ & $\mathrm{ns}^{\mathrm{d}}$ & ns & * & ns & ns \\
\hline \multirow[t]{7}{*}{ Milan } & 1 & 17.1 & 24.6 & 14.5 & 18.9 & $16.6 \mathrm{~d}$ \\
\hline & 2 & 18.1 & 25.1 & 15.8 & 23.0 & $21.9 \mathrm{bcd}$ \\
\hline & 3 & 16.5 & 27.3 & 15.3 & 20.4 & $28.0 \mathrm{ab}$ \\
\hline & 4 & 14.6 & 28.6 & 17.6 & 13.8 & $26.3 b c$ \\
\hline & 5 & 20.4 & 30.0 & 19.8 & 18.6 & $35.1 \mathrm{a}$ \\
\hline & 6 & 16.9 & 21.4 & 11.6 & 18.0 & $19.1 \mathrm{~cd}$ \\
\hline & Sig & ns & ns & ns & ns & $* *$ \\
\hline
\end{tabular}

${ }^{*}$ Significant at 0.05 probability level; ${ }^{*}$ Significant at 0.01 probability level. ${ }^{a}$ Treatments $1,2,3,4$, and 5 were the annual $\mathrm{P}$ application rates of $0,10,20,30$, and $40 \mathrm{~kg} \cdot \mathrm{P} \cdot \mathrm{ha}^{-1}$, respectively; treatment 6 was the P fertilizer recommended rate based on soil $\mathrm{P}$ testing results every year. ${ }^{\mathrm{b}}$ Means in a column within each location followed by the same letter are not significantly different at $\mathrm{P}=0.05$ according to the protected LSD. ${ }^{\mathrm{c}} \mathrm{Sig}$, significance. ${ }^{\mathrm{d}} \mathrm{ns}$, not significant at 0.05 probability level. 


\subsection{Leaf $P$ Concentrations}

Phosphorus fertilization effects were occasionally significant on soybean leaf $\mathrm{P}$ concentrations at the V5, R1, and R3 growth stages in this study (Table 3). At Jackson and Milan, leaf P levels measured at V5 in 2009 and 2011 generally increased with increasing $\mathrm{P}$ rate. Overall, $\mathrm{P}$ rates seemed to have greater impacts on leaf $\mathrm{P}$ at $\mathrm{V} 5$ than at $\mathrm{R} 1$ and $\mathrm{R} 3$ at both locations. As $\mathrm{P}$ application rate went up, the increase in leaf $\mathrm{P}$ gradually slowed down.

Campbell and Plank (2011) [34] recommended that the range of adequate leaf $\mathrm{P}$ concentrations was 3.0 to $6.0 \mathrm{~g} \mathrm{~kg}^{-1}$ at both the early growth and flowering stages for soybean grown in the southern United States. According to these criteria, leaf P concentrations were mostly below the lower limit of the sufficient ranges regardless of growth stage and location in 2008, which was a dry year. In 2009, leaf P concentrations were almost all below the sufficiency ranges at V5 and R1 but above them at R3 irrespective of treatment and location. However, leaf $\mathrm{P}$ levels were above the lower limit of the sufficiency ranges at both locations in 2010 and 2011 except R3 at Milan in 2011. Therefore, soybean yield responses to $\mathrm{P}$ applications were not expected at any location in any year based on the sufficient leaf $\mathrm{P}$ concentrations with the zero $\mathrm{P}$ treatment, or no significant improvement in leaf $\mathrm{P}$ with $\mathrm{P}$ applications.

Table 3. Phosphorus fertilization effects on leaf $\mathrm{P}$ concentrations at Jackson and Milan from 2008 to 2011.

\begin{tabular}{|c|c|c|c|c|c|c|c|c|c|c|c|c|c|}
\hline \multirow{2}{*}{ Location } & \multirow{2}{*}{ Treatment $^{\mathrm{a}}$} & \multicolumn{3}{|c|}{2008} & \multicolumn{3}{|c|}{2009} & \multicolumn{3}{|c|}{2010} & \multicolumn{3}{|c|}{2011} \\
\hline & & $\mathrm{V} 5^{\mathrm{b}}$ & $\mathrm{R} 1$ & R3 & V5 & $\mathrm{R} 1$ & R3 & V5 & $\mathrm{R} 1$ & R3 & V5 & $\mathrm{R} 1$ & R3 \\
\hline & & \multicolumn{12}{|c|}{$\mathrm{g} \cdot \mathrm{kg}^{-1}$} \\
\hline \multirow[t]{7}{*}{ Jackson } & 1 & 2.60 & 2.93 & 2.77 & $2.35 b^{c}$ & 2.76 & $3.21 \mathrm{c}$ & 3.40 & 3.57 & 3.50 & $3.81 \mathrm{bc}$ & $3.54 \mathrm{~b}$ & 3.26 \\
\hline & 2 & 2.59 & 2.88 & 2.63 & $2.54 \mathrm{~b}$ & 2.69 & $3.38 \mathrm{abc}$ & 3.61 & 3.66 & 3.29 & $3.48 c$ & $3.58 \mathrm{~b}$ & 2.97 \\
\hline & 3 & 2.67 & 3.11 & 2.71 & $2.54 \mathrm{~b}$ & 2.81 & $3.36 \mathrm{bc}$ & 3.40 & 3.79 & 3.54 & $4.15 b$ & $3.63 b$ & 3.46 \\
\hline & 4 & 2.52 & 2.80 & 2.69 & $2.53 \mathrm{~b}$ & 2.84 & $3.43 \mathrm{ab}$ & 3.83 & 3.99 & 3.42 & $4.13 \mathrm{~b}$ & $4.07 \mathrm{a}$ & 3.37 \\
\hline & 5 & 2.59 & 3.21 & 2.80 & $3.09 \mathrm{a}$ & 3.00 & $3.55 a$ & 4.03 & 4.07 & 3.64 & $4.71 \mathrm{a}$ & $3.98 \mathrm{a}$ & 3.35 \\
\hline & 6 & 2.59 & 3.09 & 2.76 & $2.72 \mathrm{ab}$ & 2.89 & $3.44 \mathrm{ab}$ & 3.49 & 3.88 & 3.51 & $3.80 \mathrm{bc}$ & $3.75 \mathrm{ab}$ & 3.29 \\
\hline & $\mathrm{Sig}^{\mathrm{d}}$ & $\mathrm{ns}^{\mathrm{e}}$ & ns & ns & * & ns & * & ns & ns & ns & $* *$ & * & ns \\
\hline \multirow[t]{7}{*}{ Milan } & 1 & 2.26 & 2.66 & 2.88 & $2.48 \mathrm{a}$ & 2.23 & 3.50 & 3.75 & 3.48 & 3.39 & $4.33 \mathrm{~b}$ & 4.18 & 2.62 \\
\hline & 2 & 2.37 & 2.72 & 2.80 & $2.53 \mathrm{a}$ & 2.40 & 3.99 & 3.87 & 3.74 & 3.37 & $4.30 \mathrm{~b}$ & 4.24 & 2.87 \\
\hline & 3 & 2.43 & 2.61 & 2.69 & $2.52 \mathrm{a}$ & 2.35 & 3.66 & 3.75 & 3.46 & 3.47 & $4.50 \mathrm{ab}$ & 4.21 & 2.76 \\
\hline & 4 & 2.36 & 2.69 & 2.97 & $2.59 \mathrm{a}$ & 2.26 & 3.70 & 3.95 & 3.46 & 3.47 & $4.65 a$ & 4.26 & 2.87 \\
\hline & 5 & 2.43 & 2.67 & 2.75 & $2.64 \mathrm{a}$ & 2.31 & 4.13 & 4.13 & 3.70 & 3.35 & $4.40 \mathrm{~b}$ & 4.20 & 2.80 \\
\hline & 6 & 2.32 & 2.50 & 2.85 & $2.16 \mathrm{~b}$ & 2.15 & 3.97 & 3.84 & 3.66 & 3.26 & $4.47 \mathrm{ab}$ & 4.35 & 2.73 \\
\hline & Sig & ns & ns & ns & * & $\mathrm{ns}$ & ns & ns & ns & ns & * & ns & ns \\
\hline
\end{tabular}

${ }^{*}$ Significant at 0.05 probability level; ${ }^{* *}$ Significant at 0.01 probability level. ${ }^{a}$ Treatments $1,2,3,4$, and 5 were the annual P application rates of $0,10,20,30$, and $40 \mathrm{~kg} \cdot \mathrm{P} \cdot \mathrm{ha}^{-1}$, respectively; treatment 6 was the P fertilizer recommended rate based on soil $\mathrm{P}$ testing results every year. ${ }^{\mathrm{b}} \mathrm{V}$, 5 -leaf growth stage; $\mathrm{R} 1$, beginning flowering stage; $\mathrm{R}$ 3, beginning pod stage. ${ }^{\mathrm{c}}$ Means in a column within each location followed by the same letter are not significantly different at $\mathrm{P}=$ 0.05 according to the protected LSD. ${ }^{\mathrm{d}}$ Sig, significance. ${ }^{\mathrm{e}} \mathrm{ns}$, not significant at 0.05 probability level. 


\subsection{Seed Yield and P Concentrations}

At Jackson, soybean seed yield did not respond to $\mathrm{P}$ applications in any year or on the four-year averages (Table 4). However, a trend of increase in seed yield was observed when $\mathrm{P}$ application rate went up from 0 to 30 or $40 \mathrm{~kg} \cdot \mathrm{P} \cdot \mathrm{ha}^{-1}$ regardless of year. Seed yields varied among the four growing seasons with higher yields in 2008, 2009, and 2010 than those in 2011.

At Milan, seed yield responded to $\mathrm{P}$ application averaged over the four years (Table 4). Applying $10 \mathrm{~kg} \cdot \mathrm{P} \cdot \mathrm{ha}^{-1}$ produced the highest yield out of the six treatments on the four-year averages. Seed yields differed among the four years with higher yields in 2009 and 2010 than those in 2008 and 2011.

Significant responses of seed $\mathrm{P}$ concentrations to $\mathrm{P}$ applications were observed at both locations in 2010 only (Table 5), which suggests that $P$ treatment effects on seed $P$ level may depend on environmental conditions and is not consistent. There seemed to be a tendency of increase in seed $\mathrm{P}$ when $\mathrm{P}$ application rate was increased from 0 till 30 or $40 \mathrm{~kg} \cdot \mathrm{P} \cdot \mathrm{ha}^{-1}$ in all three years at Jackson only.

Overall, our results showed that soybean yields did not respond significantly to the $\mathrm{P}$ application rates at either location in this study. Soybean has been classified as a poor responder to $\mathrm{P}$ fertilization compared with other row crops although responses have been observed in low-testing soils [35]. Large soybean yield responses to P fertilization have been reported [36]-[40], but these responses were frequent observed when soils tested very low or low.

\subsection{Protein, Oil, and Fatty Acid Concentrations}

Both protein and oil concentrations in seed differed among $\mathrm{P}$ application rates at Jackson in 2009 and 2010 and averaged over the three years (Table 5). The fact that significant protein and oil responses to P fertilization in 2009 and 2010 but not in 2008 at Jackson might be attributable to the accumulated treatment effects over the years. At Milan, protein concentrations responded to P rates in 2009 and on the three-year averages; while oil concentrations were not affected by $\mathrm{P}$ applications in any year (Table 5). In general, protein concentrations were enhanced with increased $\mathrm{P}$ application rates, but oil levels decreased when $\mathrm{P}$ rate was increased at both locations. The year effects on protein and oil concentrations were significant at both locations.

It is well known that $\mathrm{P}$ deficiency reduces soybean leaf area and the number of leaves, nodes, and branches; P-deficient plants exhibit reduced carbohydrate supply to nodules and decreased nodule weight, number, and functioning, such as reduced nitrogenase activity of the nodule. Therefore, $\mathrm{P}$ fertilization increases $\mathrm{N}$ fixation when soybean is deficient in $\mathrm{P}$, and thus enhances protein concentration in soybean seed.

Concentrations of the fatty acids in seed oil responded differently to $\mathrm{P}$ application rates at both locations (Table 6). At Jackson, the responses of palmitic and oleic acid concentrations to $\mathrm{P}$ rates were significant and positive in 2009 and 2010 and on the 
Table 4. Phosphorus fertilization effects on seed yield at Jackson and Milan from 2008 to 2011.

\begin{tabular}{|c|c|c|c|}
\hline \multirow{2}{*}{ Year } & \multirow{2}{*}{ Treatment ${ }^{\mathrm{a}}$} & Jackson & Milan \\
\hline & & \multicolumn{2}{|c|}{$\mathrm{Mg} \cdot \mathrm{ha}^{-1}$} \\
\hline \multirow[t]{7}{*}{2008} & 1 & 2.45 & 2.28 \\
\hline & 2 & 2.55 & 2.37 \\
\hline & 3 & 2.48 & 2.22 \\
\hline & 4 & 2.49 & 2.33 \\
\hline & 5 & 2.61 & 2.27 \\
\hline & 6 & 2.51 & 2.29 \\
\hline & $\mathrm{Sig}^{\mathrm{b}}$ & $n s^{c}$ & $\mathrm{~ns}$ \\
\hline \multirow[t]{7}{*}{2009} & 1 & 2.42 & 2.92 \\
\hline & 2 & 2.59 & 2.91 \\
\hline & 3 & 2.50 & 2.56 \\
\hline & 4 & 2.46 & 2.90 \\
\hline & 5 & 2.52 & 2.72 \\
\hline & 6 & 2.61 & 2.73 \\
\hline & Sig & $\mathrm{ns}$ & $\mathrm{ns}$ \\
\hline \multirow[t]{7}{*}{2010} & 1 & 2.74 & 2.71 \\
\hline & 2 & 2.63 & 2.99 \\
\hline & 3 & 2.77 & 2.79 \\
\hline & 4 & 2.83 & 2.80 \\
\hline & 5 & 2.82 & 2.69 \\
\hline & 6 & 2.82 & 2.70 \\
\hline & Sig & $\mathrm{ns}$ & $\mathrm{ns}$ \\
\hline \multirow[t]{7}{*}{2011} & 1 & 2.08 & 2.14 \\
\hline & 2 & 2.19 & 2.23 \\
\hline & 3 & 2.06 & 2.18 \\
\hline & 4 & 2.03 & 2.21 \\
\hline & 5 & 2.29 & 2.14 \\
\hline & 6 & 2.01 & 2.22 \\
\hline & Sig & $\mathrm{ns}$ & ns \\
\hline \multirow[t]{6}{*}{ Average } & 1 & 2.42 & $2.51 \mathrm{ab}^{\mathrm{d}}$ \\
\hline & 2 & 2.49 & $2.63 \mathrm{a}$ \\
\hline & 3 & 2.45 & $2.44 \mathrm{~b}$ \\
\hline & 4 & 2.45 & $2.56 \mathrm{ab}$ \\
\hline & 5 & 2.56 & $2.45 b$ \\
\hline & 6 & 2.49 & $2.48 \mathrm{~b}$ \\
\hline \multirow[t]{4}{*}{ Year } & 2008 & $2.51 \mathrm{~b}$ & $2.29 b$ \\
\hline & 2009 & $2.52 \mathrm{~b}$ & $2.79 \mathrm{a}$ \\
\hline & 2010 & $2.77 \mathrm{a}$ & $2.78 \mathrm{a}$ \\
\hline & 2011 & $2.11 \mathrm{c}$ & $2.19 \mathrm{~b}$ \\
\hline \multirow[t]{3}{*}{ Sig } & $\mathrm{Trt}^{\mathrm{e}}$ & ns & * \\
\hline & Year & $* * *$ & $* * *$ \\
\hline & Trt $\times$ Year & ns & ns \\
\hline
\end{tabular}

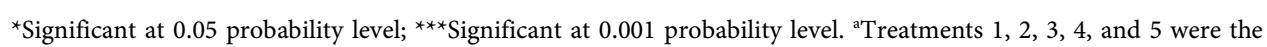
annual $\mathrm{P}$ application rates of $0,10,20,30$, and $40 \mathrm{~kg} \cdot \mathrm{P} \cdot \mathrm{ha}^{-1}$, respectively; treatment 6 was the $\mathrm{P}$ fertilizer recommended rate based on soil P testing results every year. ${ }^{\mathrm{b}} \mathrm{Sig}$, significance. ${ }^{\mathrm{c}} \mathrm{ns}$, not significant at 0.05 probability level. ${ }^{\mathrm{d}}$ Means in a column within each year, averaged over the four years, or averaged over the six treatments followed by the same letter are not significantly different at $\mathrm{P}=0.05$ according to the protected LSD. ${ }^{\mathrm{e}} \mathrm{Trt}$, treatment. 
Table 5. Phosphorus fertilization effects on the concentrations of seed P, protein, and oil at Jackson and Milan from 2008 to 2010.

\begin{tabular}{|c|c|c|c|c|c|c|c|}
\hline \multirow{2}{*}{ Year } & \multirow{2}{*}{ Treatment $^{\mathrm{a}}$} & \multicolumn{3}{|c|}{ Jackson } & \multicolumn{3}{|c|}{ Milan } \\
\hline & & Seed P & Protein & Oil & Seed P & Protein & Oil \\
\hline & & \multicolumn{6}{|c|}{$\mathrm{g} \cdot \mathrm{kg}^{-1}$} \\
\hline \multirow[t]{7}{*}{2008} & 1 & 5.40 & 437 & 205 & 5.50 & 405 & 220 \\
\hline & 2 & 5.48 & 433 & 205 & 5.73 & 403 & 221 \\
\hline & 3 & 5.55 & 431 & 203 & 5.55 & 407 & 220 \\
\hline & 4 & 5.35 & 430 & 207 & 5.45 & 406 & 220 \\
\hline & 5 & 5.53 & 432 & 205 & 5.50 & 404 & 218 \\
\hline & 6 & 5.58 & 435 & 207 & 5.30 & 407 & 219 \\
\hline & $\operatorname{Sig}^{\mathrm{b}}$ & $\mathrm{ns}^{\mathrm{c}}$ & ns & $\mathrm{ns}$ & ns & ns & ns \\
\hline \multirow[t]{7}{*}{2009} & 1 & 5.80 & $410 c^{d}$ & $244 a$ & 6.04 & $412 \mathrm{~b}$ & 228 \\
\hline & 2 & 5.80 & $433 b$ & $225 c$ & 5.90 & $441 \mathrm{a}$ & 225 \\
\hline & 3 & 5.83 & $432 \mathrm{~b}$ & $232 \mathrm{bc}$ & 6.05 & $438 \mathrm{a}$ & 225 \\
\hline & 4 & 5.95 & $433 b$ & $234 \mathrm{~b}$ & 5.90 & $433 a$ & 226 \\
\hline & 5 & 6.01 & $441 \mathrm{a}$ & $233 b c$ & 6.03 & $436 a$ & 224 \\
\hline & 6 & 5.90 & $436 \mathrm{ab}$ & $238 \mathrm{ab}$ & 5.84 & $440 \mathrm{a}$ & 224 \\
\hline & Sig & $\mathrm{ns}$ & $* * *$ & $* *$ & $\mathrm{~ns}$ & $* * *$ & ns \\
\hline \multirow[t]{7}{*}{2010} & 1 & $6.66 c$ & $445 c$ & $198 \mathrm{a}$ & $6.22 \mathrm{~b}$ & 420 & 202 \\
\hline & 2 & $7.09 a$ & $448 \mathrm{bc}$ & $195 \mathrm{ab}$ & $6.20 \mathrm{~b}$ & 421 & 203 \\
\hline & 3 & $6.85 b c$ & $446 c$ & $199 a$ & $6.51 \mathrm{a}$ & 422 & 201 \\
\hline & 4 & $6.92 \mathrm{ab}$ & $459 a$ & $190 c$ & 6.39ab & 422 & 200 \\
\hline & 5 & $6.85 b c$ & $454 \mathrm{ab}$ & $191 b c$ & $6.24 \mathrm{~b}$ & 422 & 204 \\
\hline & 6 & $6.80 \mathrm{bc}$ & $451 b c$ & $199 a$ & $6.30 \mathrm{~b}$ & 423 & 203 \\
\hline & Sig & * & * & $* *$ & * & ns & ns \\
\hline \multirow[t]{6}{*}{ Average } & 1 & 5.96 & $431 d$ & $216 a$ & 5.92 & $412 \mathrm{~b}$ & 217 \\
\hline & 2 & 6.12 & $438 \mathrm{bc}$ & $208 \mathrm{~d}$ & 5.94 & $422 a$ & 216 \\
\hline & 3 & 6.08 & $436 c$ & $212 b c$ & 6.04 & $422 a$ & 216 \\
\hline & 4 & 6.07 & $441 \mathrm{ab}$ & $210 \mathrm{~cd}$ & 5.91 & $420 \mathrm{a}$ & 215 \\
\hline & 5 & 6.13 & $442 \mathrm{a}$ & $210 \mathrm{~cd}$ & 5.92 & $421 \mathrm{a}$ & 215 \\
\hline & 6 & 6.12 & $441 \mathrm{ab}$ & $214 \mathrm{ab}$ & 5.81 & $423 a$ & 216 \\
\hline \multirow[t]{3}{*}{ Year } & 2008 & $5.48 \mathrm{c}$ & $433 b$ & $205 b$ & $5.50 \mathrm{c}$ & $405 c$ & $220 \mathrm{~b}$ \\
\hline & 2009 & $5.88 \mathrm{~b}$ & $431 b$ & $234 \mathrm{a}$ & $5.96 \mathrm{~b}$ & $433 a$ & $225 \mathrm{a}$ \\
\hline & 2010 & $6.86 a$ & $450 \mathrm{a}$ & $195 c$ & $6.31 \mathrm{a}$ & $421 b$ & $202 \mathrm{c}$ \\
\hline \multirow[t]{3}{*}{ Sig } & $\operatorname{Trt}^{\mathrm{e}}$ & ns & $* * *$ & $* * *$ & ns & $* * *$ & ns \\
\hline & Year & $* * *$ & $* * *$ & $* * *$ & $* * *$ & $* * *$ & $* * *$ \\
\hline & Trt $\times$ Year & $\mathrm{ns}$ & $* * *$ & $* * *$ & ns & $* * *$ & ns \\
\hline
\end{tabular}

${ }^{*}$ Significant at 0.05 probability level; ${ }^{*}$ Significant at 0.01 probability level; ${ }^{* *}$ Significant at 0.001 probability level.

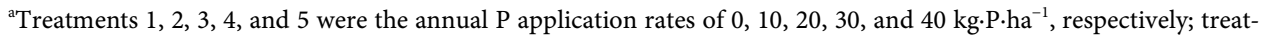
ment 6 was the P fertilizer recommended rate based on soil P testing results every year. ${ }^{b}$ Sig, significance. ${ }^{\mathrm{c} n s,}$ not significant at 0.05 probability level. ${ }^{\mathrm{d}}$ Means in a column within each year, averaged over the three years, or averaged over the six treatments followed by the same letter are not significantly different at $\mathrm{P}=0.05$ according to the protected LSD. ${ }^{\mathrm{e}}$ Trt, treatment. 
Table 6. Phosphorus fertilization effects on the concentrations of fatty acids at Jackson and Milan from 2008 to 2010 .

\begin{tabular}{|c|c|c|c|c|c|c|c|c|c|c|c|}
\hline \multirow{2}{*}{ Year } & \multirow{2}{*}{ Treatment ${ }^{\mathrm{a}}$} & \multicolumn{5}{|c|}{ Jackson } & \multicolumn{5}{|c|}{ Milan } \\
\hline & & Palmitic & Stearic & Oleic & Linoleic & Linolenic & Palmitic & Stearic & Oleic & Linoleic & Linolenic \\
\hline & & \multicolumn{5}{|c|}{ g. $\mathrm{kg}^{-1}$ oil } & \multicolumn{5}{|c|}{ g. $\mathrm{kg}^{-1}$ oil } \\
\hline \multirow[t]{7}{*}{2008} & 1 & 110 & 41.1 & 249 & 566 & 68.7 & 116 & 43.3 & 238 & 556 & 48.2 \\
\hline & 2 & 110 & 40.9 & 249 & 554 & 72.4 & 113 & 43.2 & 247 & 557 & 51.5 \\
\hline & 3 & 109 & 40.7 & 245 & 564 & 76.2 & 116 & 43.4 & 242 & 555 & 46.9 \\
\hline & 4 & 106 & 41.1 & 248 & 561 & 71.7 & 112 & 43.3 & 249 & 554 & 46.5 \\
\hline & 5 & 110 & 41.1 & 248 & 561 & 74.7 & 115 & 43.4 & 244 & 558 & 43.8 \\
\hline & 6 & 110 & 40.7 & 245 & 566 & 75.5 & 115 & 43.5 & 245 & 553 & 46.3 \\
\hline & $\mathrm{Sig}^{\mathrm{b}}$ & $\mathrm{ns}^{\mathrm{c}}$ & ns & ns & ns & ns & ns & ns & ns & ns & ns \\
\hline \multirow[t]{7}{*}{2009} & 1 & $112 \mathrm{~d}$ & 40.5 & $227 c^{d}$ & $536 \mathrm{ab}$ & $107 a$ & $117 \mathrm{~b}$ & 392 & $228 \mathrm{c}$ & $540 \mathrm{~b}$ & 90.6 \\
\hline & 2 & $144 \mathrm{ab}$ & 41.0 & $273 a b$ & $528 \mathrm{c}$ & $78.9 b$ & $136 a$ & 387 & $276 a$ & $552 a$ & 109.0 \\
\hline & 3 & $130 c$ & 40.6 & $269 b$ & $535 \mathrm{abc}$ & $80.7 \mathrm{~b}$ & $129 a b$ & 407 & $263 \mathrm{ab}$ & $540 \mathrm{~b}$ & 93.5 \\
\hline & 4 & $135 b c$ & 40.6 & $282 \mathrm{a}$ & $531 \mathrm{bc}$ & $79.1 \mathrm{~b}$ & $141 \mathrm{a}$ & 391 & $271 \mathrm{ab}$ & $539 \mathrm{~b}$ & 104.0 \\
\hline & 5 & $145 \mathrm{a}$ & 40.8 & $273 a b$ & $541 \mathrm{a}$ & $79.9 \mathrm{~b}$ & $135 a$ & 391 & $262 \mathrm{ab}$ & $550 \mathrm{a}$ & 101.0 \\
\hline & 6 & $144 \mathrm{ab}$ & 40.5 & $271 \mathrm{ab}$ & $538 \mathrm{ab}$ & $90.4 \mathrm{ab}$ & $142 \mathrm{a}$ & 391 & $256 \mathrm{~b}$ & $546 a$ & 98.4 \\
\hline & Sig & $* * *$ & ns & $* * *$ & * & * & * & ns & $* *$ & * & ns \\
\hline \multirow[t]{7}{*}{2010} & 1 & $93.4 \mathrm{bc}$ & 42.5 & $290 \mathrm{bc}$ & 539 & 65.0 & 99.0 & 43.5 & 274 & 555 & $67.9 \mathrm{~d}$ \\
\hline & 2 & $95.0 \mathrm{bc}$ & 42.5 & $283 c$ & 551 & 58.7 & 97.8 & 43.1 & 272 & 549 & $96.3 \mathrm{a}$ \\
\hline & 3 & $101 \mathrm{a}$ & 42.6 & $278 \mathrm{c}$ & 540 & 68.9 & 101 & 42.3 & 265 & 565 & $87.3 \mathrm{ab}$ \\
\hline & 4 & $91.2 \mathrm{c}$ & 42.8 & $307 a$ & 534 & 62.9 & 98.9 & 43.1 & 278 & 560 & $80.7 \mathrm{bc}$ \\
\hline & 5 & $94.1 b c$ & 42.9 & $300 \mathrm{ab}$ & 533 & 71.3 & 98.0 & 43.2 & 276 & 555 & $76.6 \mathrm{bcd}$ \\
\hline & 6 & $97.0 \mathrm{ab}$ & 42.4 & $298 \mathrm{ab}$ & 543 & 69.9 & 99.6 & 42.6 & 265 & 562 & $74.8 \mathrm{~cd}$ \\
\hline & Sig & * & ns & * & ns & ns & ns & ns & ns & ns & $* *$ \\
\hline \multirow[t]{6}{*}{ Average } & 1 & $105 c$ & 41.4 & $255 \mathrm{~d}$ & 547 & 80.4 & 111 & 42.0 & $247 d$ & 551 & $68.9 c$ \\
\hline & 2 & $115 a$ & 41.5 & $268 b c$ & 544 & 70.0 & 115 & 41.7 & $265 \mathrm{ab}$ & 553 & $85.5 \mathrm{a}$ \\
\hline & 3 & $113 \mathrm{ab}$ & 41.3 & $264 c$ & 546 & 75.3 & 115 & 42.1 & $257 b c$ & 553 & $76.9 b$ \\
\hline & 4 & $111 b$ & 41.5 & $279 a$ & 542 & 71.2 & 117 & 41.8 & $266 a$ & 551 & $77.1 \mathrm{~b}$ \\
\hline & 5 & $117 \mathrm{a}$ & 41.6 & $274 \mathrm{ab}$ & 545 & 75.3 & 116 & 41.9 & $261 \mathrm{abc}$ & 554 & $73.6 \mathrm{bc}$ \\
\hline & 6 & $117 \mathrm{a}$ & 41.2 & $268 b c$ & 549 & 78.6 & 119 & 41.7 & $255 \mathrm{~cd}$ & 554 & $73.2 \mathrm{bc}$ \\
\hline \multirow[t]{3}{*}{ Year } & 2008 & $109 \mathrm{~b}$ & $40.9 \mathrm{~b}$ & $247 c$ & $562 \mathrm{a}$ & $86.1 \mathrm{a}$ & $115 b$ & $43.4 \mathrm{a}$ & $244 \mathrm{c}$ & $556 a$ & $47.2 \mathrm{c}$ \\
\hline & 2009 & $134 a$ & $40.7 \mathrm{~b}$ & $266 \mathrm{~b}$ & $535 b$ & $73.2 \mathrm{ab}$ & $133 a$ & $39.3 \mathrm{~b}$ & $259 \mathrm{~b}$ & $545 b$ & $99.3 \mathrm{a}$ \\
\hline & 2010 & $95.2 \mathrm{c}$ & $42.6 \mathrm{a}$ & $291 \mathrm{a}$ & $540 \mathrm{~b}$ & $66.1 \mathrm{~b}$ & $98.6 c$ & $43.0 \mathrm{a}$ & $271 \mathrm{a}$ & $558 \mathrm{a}$ & $80.6 b$ \\
\hline \multirow[t]{3}{*}{ Sig } & $\mathrm{Trt}^{\mathrm{e}}$ & $* * *$ & ns & $* * *$ & ns & ns & ns & ns & $* * *$ & ns & $* * *$ \\
\hline & Year & $* * *$ & $* * *$ & $* * *$ & $* * *$ & $* * *$ & $* * *$ & $* * *$ & $* *$ & * & $* * *$ \\
\hline & Trt $\times$ Year & $* * *$ & ns & $* * *$ & $* *$ & * & $* *$ & ns & $* *$ & * & $\mathrm{ns}$ \\
\hline
\end{tabular}

${ }^{*}$ Significant at 0.05 probability level; ${ }^{*}$ Significant at 0.01 probability level; ${ }^{* *}$ Significant at 0.001 probability level. ${ }^{\text {aTTeatments }} 1,2,3,4$, and 5 were the annual $\mathrm{P}$ application rates of $0,10,20,30$, and $40 \mathrm{~kg} \cdot \mathrm{P} \cdot \mathrm{ha} \mathrm{C}^{-1}$, respectively; treatment 6 was the P fertilizer recommended rate based on soil P testing results every year. ${ }^{b}$ Sig, significance. ${ }^{\mathrm{c} n s, \text { not }}$ significant at 0.05 probability level. ${ }^{\mathrm{M}}$ Means in a column within each year, averaged over the three years, or averaged over the six treatments followed by the same letter are not significantly different at $\mathrm{P}=0.05$ according to the protected LSD. ${ }^{\mathrm{T}} \mathrm{Trt}$, treatment. 
three-year averages. Linoleic and linolenic acid levels showed significant responses to $\mathrm{P}$ applications in 2009 only. Linolenic acid concentration was reduced with P fertilization in 2009.

At Milan, $\mathrm{P}$ fertilization effects on the concentrations of palmitic and linoleic acids were significant and positive in 2009. Oleic acid responded positively to P rates in 2009 and averaged over the three years. Linolenic acid levels showed a significant and positive response to $\mathrm{P}$ application up to a certain rate in 2010 and on three-year averages. However, stearic concentration was not influenced by $\mathrm{P}$ application regardless of location and year in our study.

The fact that significant responses of several fatty acids to P fertilization in 2009 and 2010 but not in 2008 might be attributable to the accumulated treatment effects over the years at both locations. A larger number of fatty acids in response to P fertilization at both locations in 2009 might be partially resulted from the relatively lower temperatures in July 2009, because lower temperatures reduced soybean P uptake, and thus resulted in greater responses of fatty acids to $\mathrm{P}$ fertilization. On the other hand, very low rainfall in September at both locations in 2008 and 2010 might be in part responsible for no fatty acid response in 2008 and fewer significant responses of fatty acids in 2010 to $\mathrm{P}$ fertilization.

In general, palmitic and oleic acid concentrations responded to $\mathrm{P}$ fertilization positively when the responses were significant in our study. The responses of linolenic acid concentration were positive in 2009 at Jackson and positive in 2010 and on the three-year averages at Milan. There were significant differences in the concentrations of all fatty acids among the three years irrespective of location. It is interesting that protein, oil, and fatty acid concentrations sometimes responded significantly to $\mathrm{P}$ applications even when seed yield and/or seed $\mathrm{P}$ concentration did not respond to $\mathrm{P}$ fertilization.

Abbasi et al. (2012) [27] reported that $\mathrm{P}$ application increased both protein and oil concentrations in soybean seed. However, Haq and Mallarino (2005) [20] found that P fertilization increased soybean protein and oil concentrations in some trials but decreased protein and oil levels in other trials. Krueger et al. (2013) [23] reported that protein or oil concentrations in soybean seed were not affected by $\mathrm{P}$ fertilization at most locations. Gaydou and Arrivets (1983) [25], Israel et al. (2007) [28], and Krueger et al. (2013) [23] found that linoleic acid concentration decreased with P fertilization. Gaydou and Arrivets (1983) [25] and Israel et al. (2007) [28] also observed an increase in oleic acid concentration at higher $\mathrm{P}$ application rates. Krueger et al. (2013) [23] reported that linolenic acid concentration increased with excessively high $\mathrm{P}$ fertilization. The different results in seed quality attributes between our study and these prior investigations are possibly related to the differences in soil P fertility levels, cultivar characteristics, and weather conditions among these studies.

Linoleic acid concentration is a key quality attribute in soybean seed for human and animal consumption because it is an important polyunsaturated fatty acid that cannot be synthesized by humans or animals [41]. Therefore, higher levels of linoleic acid in 
the oil may increase the market value of soybean seed. The results of our study suggest that linoleic acid concentration in soybean seed can sometimes be positively affected by P fertilization.

Soybean breeders have endeavored to create new cultivars with lower linolenic acid concentration in the seed for value added cooking oil with improved health benefits [42] [43]. Our results suggest that indigenous soil P fertility level and P fertilizer application rate should be taken into account in breeding for soybean cultivars with low linolenic acid concentration since they can influence linolenic acid concentration in the seed.

Year exerted significant effects on protein, oil, and fatty acid concentrations at both locations in our study. The fact that the temperatures and rainfall were different among the four years at least partially explained the variability in $\mathrm{P}$ fertilization effects on the concentrations of protein, oil, and fatty acids among the three growing seasons.

Our results agree with those of Krueger et al. (2013) [23] in that excessive levels of P fertility decrease the quality of some attributes in soybean seed; seed quality attributes varied with treatments, locations, and years, but the variations were generally not consistent. Seed quality attributes are very important traits for soybean producers to manage because many processors place higher prices on soybean seed with desirable quality attributes.

\subsection{Production of Protein, Oil, and Fatty Acids}

At Jackson, the production of protein, oil, and fatty acids were not affected by P fertilization in any year or on the averages over the three years except linolenic acid in 2009 which was reduced due to $\mathrm{P}$ application compared with the zero $\mathrm{P}$ control (data not shown). However, the year effects were significant on all the quality attributes except palmitic acid. Protein production was higher in 2010 than those in the other two years; while the production of oil and stearic, oleic, linoleic, and linolenic acids were all higher in 2009 than those in 2008 and 2010 (data not shown).

At Milan, the production of protein, oil, and fatty acids were not influenced by $\mathrm{P}$ fertilization in any year except palmitic and oleic acids in 2009 and linolenic acid in 2010 (Table 7). In general, $\mathrm{P}$ application rate up to a certain level resulted in higher production of palmitic and oleic acids in 2009 and linolenic acid in 2010. Averaged over the three years, there was a significant $\mathrm{P}$ effect on all the quality attributes except stearic acid. Obviously, application of $10 \mathrm{~kg} \cdot \mathrm{P} \cdot \mathrm{ha}^{-1}$ resulted in higher production of protein, oil, and palmitic, oleic, linoleic, and linolenic acids than zero $\mathrm{P}$ and the higher $\mathrm{P}$ application rates as well on the three-year averages. The year effects were consistently significant on all the quality attributes; but the quality attributes responded differently to year. Both protein and stearic acid production were similar for 2009 and 2010, which were higher than those in 2008. The production of oil and palmitic, oleic, linoleic, and linolenic acids were the highest in 2010 but the lowest in 2008.

Basically the production of protein, oil, and fatty acids depend on the seed yield level and the concentrations of these attributes in the seed. Haq and Mallarino (2005) [20] 
Table 7. Phosphorus fertilization effects on the production of protein, oil, and fatty acids at Milan from 2008 to 2010 .

\begin{tabular}{|c|c|c|c|c|c|c|c|c|}
\hline \multirow{2}{*}{ Year } & \multirow{2}{*}{ Treatment $^{\mathrm{a}}$} & Protein & Oil & Palmitic & Stearic & Oleic & Linoleic & Linolenic \\
\hline & & \multicolumn{7}{|c|}{$\mathrm{kg} \cdot \mathrm{ha}^{-1}$} \\
\hline \multirow[t]{7}{*}{2008} & 1 & 921 & 501 & 57.9 & 21.7 & 119 & 279 & 24.2 \\
\hline & 2 & 955 & 524 & 59.2 & 22.6 & 129 & 292 & 27.2 \\
\hline & 3 & 900 & 488 & 56.5 & 21.2 & 118 & 271 & 22.8 \\
\hline & 4 & 949 & 514 & 57.6 & 22.3 & 128 & 285 & 23.8 \\
\hline & 5 & 917 & 495 & 56.9 & 21.4 & 121 & 276 & 21.8 \\
\hline & 6 & 930 & 501 & 57.6 & 21.8 & 123 & 278 & 23.1 \\
\hline & $\mathrm{Sig}^{\mathrm{b}}$ & $\mathrm{ns}^{\mathrm{c}}$ & ns & ns & ns & ns & ns & ns \\
\hline \multirow[t]{7}{*}{2009} & 1 & 1205 & 665 & $77.8 \mathrm{bc} c^{\mathrm{d}}$ & 26.1 & $152 c$ & 359 & 60.1 \\
\hline & 2 & 1282 & 654 & $88.6 \mathrm{ab}$ & 25.3 & $181 \mathrm{a}$ & 361 & 71.0 \\
\hline & 3 & 1123 & 578 & $74.0 \mathrm{c}$ & 23.5 & $152 c$ & 312 & 54.2 \\
\hline & 4 & 1253 & 656 & $92.5 \mathrm{a}$ & 25.6 & $178 \mathrm{ab}$ & 354 & 68.5 \\
\hline & 5 & 1187 & 609 & $82.5 \mathrm{abc}$ & 23.8 & $160 \mathrm{abc}$ & 334 & 61.2 \\
\hline & 6 & 1201 & 613 & $87.0 \mathrm{ab}$ & 24.0 & $157 b c$ & 335 & 60.6 \\
\hline & Sig & ns & ns & * & ns & * & ns & ns \\
\hline \multirow[t]{7}{*}{2010} & 1 & 1137 & 547 & 54.1 & 23.8 & 150 & 303 & $37.1 \mathrm{c}$ \\
\hline & 2 & 1256 & 606 & 59.3 & 26.1 & 165 & 333 & $58.9 \mathrm{a}$ \\
\hline & 3 & 1174 & 560 & 56.3 & 23.7 & 149 & 316 & $48.9 \mathrm{~b}$ \\
\hline & 4 & 1180 & 559 & 54.1 & 24.1 & 155 & 313 & $45.1 \mathrm{bc}$ \\
\hline & 5 & 1132 & 547 & 53.6 & 23.6 & 151 & 303 & $41.8 \mathrm{bc}$ \\
\hline & 6 & 1141 & 549 & 54.6 & 23.5 & 146 & 308 & $41.3 \mathrm{bc}$ \\
\hline & Sig & ns & ns & ns & ns & $\mathrm{ns}$ & ns & $* *$ \\
\hline \multirow[t]{6}{*}{ Average } & 1 & $1088 \mathrm{~b}$ & $571 \mathrm{abc}$ & $63.2 \mathrm{~b}$ & 23.8 & $140 \mathrm{c}$ & $314 \mathrm{ab}$ & $40.5 b$ \\
\hline & 2 & $1164 \mathrm{a}$ & $595 a$ & $69.0 \mathrm{a}$ & 24.7 & $158 \mathrm{a}$ & $329 a$ & $52.4 \mathrm{a}$ \\
\hline & 3 & $1066 \mathrm{~b}$ & $542 c$ & $62.3 \mathrm{~b}$ & 22.8 & $139 \mathrm{c}$ & $300 \mathrm{~b}$ & $42.0 \mathrm{~b}$ \\
\hline & 4 & $1128 \mathrm{ab}$ & $576 a b$ & $68.1 \mathrm{a}$ & 24.0 & $154 \mathrm{ab}$ & $317 \mathrm{ab}$ & $45.8 \mathrm{~b}$ \\
\hline & 5 & $1079 b$ & $550 \mathrm{bc}$ & $64.3 \mathrm{ab}$ & 23.0 & $144 \mathrm{bc}$ & $305 b$ & $41.6 \mathrm{~b}$ \\
\hline & 6 & $1091 b$ & $555 \mathrm{bc}$ & $66.4 \mathrm{ab}$ & 23.1 & $142 \mathrm{c}$ & $307 \mathrm{~b}$ & $41.7 \mathrm{~b}$ \\
\hline \multirow[t]{3}{*}{ Year } & 2008 & $929 b$ & $504 c$ & $57.6 \mathrm{~b}$ & $21.8 \mathrm{~b}$ & $123 c$ & $280 \mathrm{c}$ & $23.8 \mathrm{c}$ \\
\hline & 2009 & $1209 a$ & $629 a$ & $83.8 \mathrm{a}$ & $24.7 \mathrm{a}$ & $163 a$ & $343 a$ & $63.0 \mathrm{a}$ \\
\hline & 2010 & $1170 \mathrm{a}$ & $561 \mathrm{~b}$ & $55.3 \mathrm{~b}$ & $24.1 \mathrm{a}$ & $153 b$ & $313 b$ & $45.5 \mathrm{~b}$ \\
\hline \multirow[t]{3}{*}{ Sig } & $\operatorname{Trt}^{\mathrm{e}}$ & * & * & * & ns & $* *$ & * & $* * *$ \\
\hline & Year & $* * *$ & $* * *$ & $* * *$ & $* *$ & $* * *$ & $* *$ & $* * *$ \\
\hline & Trt $\times$ Year & ns & ns & ns & ns & ns & ns & ns \\
\hline
\end{tabular}

${ }^{*}$ Significant at 0.05 probability level; ${ }^{*}$ Significant at 0.01 probability level; ${ }^{* *}$ Significant at 0.001 probability level. ${ }^{a}$ Treatments $1,2,3,4$, and 5 were the annual $\mathrm{P}$ application rates of $0,10,20,30$, and $40 \mathrm{~kg} \cdot \mathrm{P} \cdot \mathrm{ha} \mathrm{C}^{-1}$, respectively; treatment 6 was the P fertilizer recommended rate based on soil P testing results every year. Sig, significance. ' $n$, not significant at 0.05 probability level. ${ }^{\mathrm{d}}$ Means in a column within each year, averaged over the three years, or averaged over the six treatments followed by the same letter are not significantly different at $\mathrm{P}=0.05$ according to the protected LSD. ${ }^{\mathrm{e}}$ Trt, treatment. 
found that protein and oil production responses to $\mathrm{P}$ fertilization tended to follow yield responses; P fertilization that increases soybean yield has infrequent, inconsistent, and small effects on oil and protein concentrations but often increases oil and protein production.

\section{Conclusions}

Phosphorus application rates had greater impacts on leaf $\mathrm{P}$ nutrition at the earlier growth stages. As $\mathrm{P}$ application rate went up, the increase in leaf $\mathrm{P}$ gradually slowed down. Protein, oil, and fatty acid concentrations in seed responded differently to P fertilization. In general, protein concentrations were enhanced but oil levels decreased with increased $\mathrm{P}$ application rate. Palmitic and oleic concentrations responded positively to $\mathrm{P}$ application rate up to a certain level. However, the response of linolenic acid concentration was inconsistent (negative or positive). Stearic concentration was not influenced by P fertilization. Application of $10 \mathrm{~kg} \cdot \mathrm{P} \cdot \mathrm{ha}^{-1}$ resulted in higher production of protein and palmitic, oleic, and linolenic acids than zero $\mathrm{P}$ and the higher $\mathrm{P}$ application rates as well on the $\mathrm{P}$ deficient soil. Excessive $\mathrm{P}$ application rates could lower seed yield and the quality of some attributes in seed. Our results suggest that linoleic acid concentration, a key quality attribute in soybean seed for human and animal consumption, can sometimes be enhanced by $\mathrm{P}$ fertilization, and thus appropriate $\mathrm{P}$ application may increase the market value of soybean production; the indigenous soil P fertility level and $\mathrm{P}$ application rate should be taken into account by soybean breeders in breeding for new soybean cultivars with low linolenic acid level since $P$ can affect linolenic acid level in the seed.

\section{Acknowledgements}

This research was partially supported by the Tennessee Soybean Promotion Board. We thank Robert Sharp, James Warren, Jimmy McClure, and Jason Williams for their skilful technical assistance.

\section{References}

[1] Hartwig, E.E. and Kilen, T.C. (1991) Yield and Composition of Soybean Seed from Parents with Different Protein, Similar Yield. Crop Science, 31, 290-292. http://dx.doi.org/10.2135/cropsci1991.0011183X003100020011x

[2] Bellaloui, N., Smith, J.R., Gillen, A.M. and Ray, J.D. (2010) Effect of Maturity on Seed Sugars as Measured on Near-Isogenic Soybean (Glycine max) Lines. Crop Science, 50, 19781987. http://dx.doi.org/10.2135/cropsci2009.10.0596

[3] Wang, C., Sherrard, M., Pagadola, S., Wixon, R. and Scott, R.A. (2000) Isoflavone Content among Maturity Group 0 to II Soybeans. Journal of the American Oil Chemists' Society, 77, 483-487. http://dx.doi.org/10.1007/s11746-000-0077-6

[4] Wilson, R.F. (2004) Seed Composition. In: Boerma, H.R. and Specht, J.E., Eds., Soybeans. Improvement, Production, and Uses, 3rd Edition, ASA Monogr. 16. ASA, Madison, WI. 621-669.

[5] Yin, X.H. and Vyn, T.J. (2005) Relationships of Isoflavone, Oil, and Protein in Seed with 
Yield of Soybean. Agronomy Journal, 97, 1314-1321.

http://dx.doi.org/10.2134/agronj2004.0316

[6] Helms, T.C. and Orf, J.H. (1998) Protein, Oil, and Yield of Soybean Lines Selected for Increased Protein. Crop Science, 38, 707-711. http://dx.doi.org/10.2135/cropsci1998.0011183X003800030015x

[7] Dardanelli, J.L., Balzarini, M., Martinez, M.J., Cuniberti, M., Resnik, S., Ramunda, S.F., Herrero, R. and Baigorri, H. (2006) Soybean Maturity Groups, Environments, and Their Interaction Define Mega-Environments for Seed Composition in Argentina. Crop Science, 46, 1939-1947. http://dx.doi.org/10.2135/cropsci2005.12-0480

[8] Westgate, M.E., Piper, E., Batchelor, W.D. and Hurburgh Jr., C.R. (1999) Effects of Cultural and Environmental Conditions during Soybean Growth on Nutritive Value of Soy Products. Proceedings of Global Soybeans Forum, Chicago, IL, 4-7 August 1999, 75-89.

[9] Bellaloui, N., Smith, J.R., Ray, J.D. and Gillen, A.M. (2009) Effect of Maturity on Seed Composition in the Early Soybean Production System as Measured on Near-Isogenic Soybean Lines. Crop Science, 49, 608-620. http://dx.doi.org/10.2135/cropsci2008.04.0192

[10] Bellaloui, N., Mengistu, A., Fisher, D.K. and Abel, C.A. (2012) Soybean Seed Composition Constituents as Affected by Drought and Phomopsis in Phomopsis Susceptible and Resistant Genotypes. Journal of Crop Improvement, 26, 428-453. http://dx.doi.org/10.1080/15427528.2011.651774

[11] Bellaloui, N., Mengistu, A., Zobiole, L.H.S. and Shier, W.T. (2012b) Resistance to ToxinMediated Fungal Infection: Role of Lignins, Isoflavones, Other Seed Phenolics, Sugars, and Boron in the Mechanism of Resistance to Charcoal Rot Disease in Soybean. Toxin Reviews, 31, 16-26. http://dx.doi.org/10.3109/15569543.2012.691150

[12] Bellaloui, N., Reddy, K.N., Gillen, A.M., Fisher, D.K. and Mengistu, A. (2011) Influence of Planting Date on Seed Protein, Oil, Sugars, Minerals, and Nitrogen Metabolism in Soybean under Irrigated and Non-Irrigated Environments. American Journal of Plant Sciences, 2, 702-715. http://dx.doi.org/10.4236/ajps.2011.25085

[13] Helms, T.C., Hurburgh Jr., C.R., Lussenden, R.L. and Whited, D.A. (1990) Economic Analysis of Increased Protein and Decreased Yield due to Delayed Planting of Soybean. Journal of Production Agriculture, 3, 367-371. http://dx.doi.org/10.2134/jpa1990.0367

[14] Specht, J.E., Chase, K., Macrander, M., Graef, G.L., Chung, J., Markwell, J.P., Orf, H.H. and Lark, K.G. (2001) Soybean Response to Water: A QTL Analysis of Drought Tolerance. Crop Science, 41, 493-509. http://dx.doi.org/10.2135/cropsci2001.412493x

[15] Kravchenko, A.N. and Bullock, D.G. (2002) Spatial Variability of Soybean Quality Data as a Function of Field Topography: II. A Proposed Technique for Calculating the Size of the Area for Differential Soybean Harvest. Crop Science, 42, 816-821. http://dx.doi.org/10.2135/cropsci2002.0816

[16] Kravchenko, A.N. and Bullock, D.G. (2002) Spatial Variability of Soybean Quality Data as a Function of Field Topography: I. Spatial Data Analysis. Crop Science, 42, 804-815. http://dx.doi.org/10.2135/cropsci2002.0804

[17] Yin, X.H. and Vyn, T.J. (2003) Potassium Placement Effects on Yield and Seed Composition of No-Till Soybean Seeded in Alternate Row Widths. Agronomy Journal, 95, 126-132. http://dx.doi.org/10.2134/agronj2003.0126

[18] Burton, J.W. (1985) Breeding Soybeans for Improved Protein Quantity and Quality. Proceedings of the $3 r d$ World Soybean Research Conference, Boulder, 12-17 August 1985, 361367.

[19] Shannon Jr., G., Wilcox, J.R. and Probst, A.L. (1972) Estimated Gains from Selection for 
Protein and Yield in the $\mathrm{F}_{4}$ Generation of Six Soybean Populations. Crop Science, 12, 824826. http://dx.doi.org/10.2135/cropsci1972.0011183X001200060032x

[20] Haq, M.U. and Mallarino, A.P. (2005) Response of Soybean Grain Oil and Protein Concentrations to Foliar and Soil Fertilization. Agronomy Journal, 97, 910-918.

http://dx.doi.org/10.2134/agronj2004.0215

[21] Osborne, S.L. and Riedell, W.E. (2006) Starter Nitrogen Fertilizer Impact on Soybean Yield and Quality in the Northern Great Plains. Agronomy Journal, 98, 1569-1574. http://dx.doi.org/10.2134/agronj2006.0089

[22] Slaton, N.A., DeLong, R.E. and Ross, J.R. (2006) Boron Fertilization Influences on Soybean Yield and Leaf and Seed Boron Concentrations. Agronomy Journal, 98, 198-205. http://dx.doi.org/10.2134/agronj2005-0131

[23] Krueger, K., Goggi, A.S., Mallarino, A.P. and Mullen, R.E. (2013) Phosphorus and Potassium Fertilization Effects on Soybean Seed Quality and Composition. Crop Science, 53, 602-610. http://dx.doi.org/10.2135/cropsci2012.06.0372

[24] Adeli, A., Sistani, K.R., Rowe, D.E. and Tewolde, H. (2005) Effects of Broiler Litter on Soybean Production and Soil Nitrogen and Phosphorus Concentrations. Agronomy Journal, 97, 314-321. http://dx.doi.org/10.2134/agronj2005.0314

[25] Gaydou, E.M. and Arrivets, J. (1983) Effects of Phosphorus, Potassium, Dolomite, and Nitrogen-Fertilization on the Quality of Soybean-Yields, Proteins, and Lipids. Journal of Agricultural and Food Chemistry, 31, 765-769. http://dx.doi.org/10.1021/jf00118a022

[26] Seguin, P. and Zheng, W. (2006) Potassium, Phosphorus, Sulfur, and Boron Fertilization Effects on Soybean Isoflavone Content and Other Seed Characteristics. Journal of Plant Nutrition, 29, 681-698. http://dx.doi.org/10.1080/01904160600564477

[27] Abbasi, M.K., Tahir, M.M., Abbas, W.A. and Rahim, N. (2012) Soybean Yield and Chemical Composition in Response to Phosphorus-Potassium Nutrition in Kashmir. Agronomy Journal, 104, 1476-1484. http://dx.doi.org/10.2134/agronj2011.0379

[28] Israel, D.W., Kwanyuen, P., Burton, J.W. and Walker, D.R. (2007) Response of Low Seed Phytic Acid Soybeans to Increases in External Phosphorus Supply. Crop Science, 47, 20362046. http://dx.doi.org/10.2135/cropsci2006.11.0691

[29] Savoy, H.J. and Joines, D. (2009) Lime and Fertilizer Recommendations for the Various Crops of Tennessee. Chapter II. Agronomic Crops. http://soilplantandpest.utk.edu/pdffiles/soiltestandfertrecom/chap2-agronomic_mar2009.p df

[30] Sims, J.T. (1989) Comparison of Mehlich 1 and Mehlich 3 Extractants for P, K, Ca, Mg, Mn, $\mathrm{Cu}$ and $\mathrm{Zn}$ in Atlantic Coastal Plain Soils. Communications in Soil Science and Plant Analysis, 20, 1707-1726. http://dx.doi.org/10.1080/00103628909368178

[31] Gavlak, R.G., Horneck, D.A. and Miller, R.O. (1994) Plant, Soil and Water Reference Methods for the Western Region. Western Regional Extension Publication 125, University of Alaska, Fairbanks.

[32] Wilcox, J.R. and Shibles, R.M. (2001) Interrelationships among Seed Quality Attributes in Soybean. Crop Science, 41, 11-14. http://dx.doi.org/10.2135/cropsci2001.41111x

[33] Boydak, E., Alpaslan, M., Hayta, M., Gercek, S. and Simsek, M. (2002) Seed Composition of Soybeans Grown in the Harran Region of Turkey as Affected by Row Spacing and Irrigation. Journal of Agricultural and Food Chemistry, 50, 4718-4720. http://dx.doi.org/10.1021/jf0255331

[34] Campbell, C.R. and Plank, C.O. (2011) Corn. In Campbell C.R., Ed., Reference Sufficiency Ranges for Plant Analysis in the Southern Region of the United States South, Cooperative 
Series Bulletin No. 394, Southern Region Agricultural Experiment Stations, 33-34.

[35] Kamprath, E.J. (1974) Nutrition Relationship to Soybean Fertilization, Soybean Production, Marketing and Use. In: Tennessee Valley Authority Bull, Y-69, Tennessee Valley Authority, Knoxville, 28-32.

[36] Bharati, M.P., Whigham, D.K. and Voss, R.D. (1986) Soybean Response to Tillage and Nitrogen, Phosphorus, and Potassium Fertilization. Agronomy Journal, 78, 947-950. http://dx.doi.org/10.2134/agronj1986.00021962007800060002x

[37] Borges, R. and Mallarino, A.P. (2000) Grain Yield and Early Growth, and Nutrient Uptake of No-Till Soybean as Affected by the Phosphorus and Potassium Placement. Agronomy Journal, 92, 380-388. http://dx.doi.org/10.2134/agronj2000.922380x

[38] Borges, R. and Mallarino, A.P. (2003) Broadcast and Deep-Band Placement of Phosphorus and Potassium for Soybean Managed with Ridge Tillage. Soil Science Society of America Journal, 67, 1920-1927. http://dx.doi.org/10.2136/sssaj2003.1920

[39] Mallarino, A.P., Webb, J.R. and Blackmer, A.M. (1991) Corn and Soybean Yields during 11 Years of Phosphorus and Potassium Fertilization on High Testing Soil. Journal of Production Agriculture, 4, 312-317. http://dx.doi.org/10.2134/jpa1991.0312

[40] Webb, J.R., Mallarino, A.P. and Blackmer, A.M. (1992) Effect of Residual and Annually Applied Phosphorus on Soil Test Values and Yield of Corn and Soybean. Journal of Production Agriculture, 5, 148-152. http://dx.doi.org/10.2134/jpa1992.0148

[41] Carroll, K.K. (1986) Biological Effects of Fish Oils in Relation to Chronic Diseases. Lipids, 21, 731-732. http://dx.doi.org/10.1007/BF02535402

[42] Hammond, E.G. and Fehr, W.R. (1982) Progress in Breeding for Low-Linolenic Acid Soybean Oil. In: Ratledge, C., et al., Eds., Biotechnology for the Oils and Fats Industry, American Oil Chemists Society, Champaign, 89-96.

[43] Ross, A.J., Fehr, W.R., Welke, G.A. and Cianzio, S.R. (2000) Agronomic and Seed Traits of 1\%-Linolenate Soybean Genotypes. Crop Science, 40, 383-386.

http://dx.doi.org/10.2135/cropsci2000.402383x

\section{Submit or recommend next manuscript to SCIRP and we will provide best service for you:}

Accepting pre-submission inquiries through Email, Facebook, LinkedIn, Twitter, etc.

A wide selection of journals (inclusive of 9 subjects, more than 200 journals)

Providing 24-hour high-quality service

User-friendly online submission system

Fair and swift peer-review system

Efficient typesetting and proofreading procedure

Display of the result of downloads and visits, as well as the number of cited articles

Maximum dissemination of your research work

Submit your manuscript at: http://papersubmission.scirp.org/

Or contact ajps@scirp.org 